\title{
LMTK2 wt Allele
}

National Cancer Institute

\section{Source}

National Cancer Institute. LMTK2 wt Allele. NCI Thesaurus. Code C73465.

Human LMT K2 wild-type allele is located in the vicinity of $7 q 21.3$ and is approximately 99 $\mathrm{kb}$ in length. This allele, which encodes serine/threonine-protein kinase LMTK2 protein, may play a role in the regulation of both translation and protein acetylation through signal transduction. 